\title{
Financial impact of foreign exchange entering the state of Guanajuato
}

\section{Impacto financiero por la entrada de divisas al estado de Guanajuato}

GÓMEZ-BRAVO, María De La Luz*†, GOMEZ-BRAVO, Jessica Margarita, ANDRADEOSEGUERA-Miguel Ángel and BARCENAS-PUENTE José Luis

\author{
Universidad Tecnológica del Suroeste de Guanajuato \\ ID $1^{\text {st }}$ Author: María De La Luz, Gómez-Bravo / ORC ID: 0000-0002-8438-2143 \\ ID $1^{\text {st }}$ Coauthor: Jessica Margarita, Gomez-Bravo/ ORC ID: 0000-0003-4037-1925 \\ ID $2^{\text {nd }}$ Coauthor: Miguel Ángel, Andrade-Oseguera / ORC ID: 0000-0002-7926-9162 \\ ID $3^{\text {rd }}$ Coauthor: José Luis, Barcenas-Puente/ ORC ID: 0000-0002-1051-8861
}

DOI: $10.35429 / J A F .2019 .18 .6 .7 .11$

Received Mrach 20, 2019; Accepted June 29, 2019

\begin{abstract}
This work is focused on the financial impact that the state of Guanajuato has for the dozens of families that depend on the currencies sent by their relatives who are in the United States of America since these are the ones that reactivate the economy of the 46 municipalities of the state, the Currencies are almost $90 \%$ of the sources of income for families in the state. The Bank of Mexico reported that in the first half of the year more than One Thousand Two Hundred million dollars arrived, then approximately 600 million dollars are arriving in the state per quarter, this money that is sent by migrants has been destined to the basic needs of their relatives a $70 \%$ is used in food the other $30 \%$ is used in health and housing modifications. This places the state of Guanajuato in 3rd place of migrants to the neighboring country, the currencies for the state represent $6 \%$ of the Gross Domestic Product GDP of the state
\end{abstract}

\begin{abstract}
Resumen
Este trabajo está enfocado al impacto financiero que tiene el estado de Guanajuato por las decenas de familias que dependen de las divisas que mandan sus familiares que se encuentran en Estados Unidos de America, ya que estas son las que reactivan la economía de los 46 municipios del estado, las divisas son casi un $90 \%$ de las fuentes de ingresos para las familias del estado. El banco de México informo que en el primer semestre del año llegaron más de Mil Doscientos millones de dólares entonces aproximadamente por trimestre están llegando 600 millones de dólares al estado, este dinero que es enviado por migrantes se ha destinado a necesidades básicas de sus familiares un $70 \%$ se utiliza en comida el otro $30 \%$ se utiliza en salud y modificaciones de vivienda. Esto ubica al estado de Guanajuato en 3er lugar de personas migrantes al país vecino, las divisas para el estado representan un $6 \%$ del Producto Interno Bruto PIB del estado
\end{abstract}

Citation: GÓMEZ-BRAVO, María De La Luz, GOMEZ-BRAVO, Jessica Margarita, ANDRADE-OSEGUERA-Miguel Ángel and BARCENAS-PUENTE José Luis. Financial impact of foreign exchange entering the state of Guanajuato. Journal of Administration and Finance. 2019, 6-18: 7-11

\footnotetext{
*Correspondence to Author (email: mlgomezbra@utsoe.edu.mx)

$\dagger$ Researcher contributing first author.
} 


\section{Introduction}

The objective of this work is to know the financial impact of the entry of foreign currency in the state of Guanajuato, how one of the main economic inputs becomes and what is the effect of the people who receive it. In the country, the migratory phenomenon has very particular characteristics, as in the state of Guanajuato, all of them are from communities and with very low resources, as well as their level of education.

The strongest economic power is the United States of America and this has led to the flow of people in search of a better job since the salary is 8 times more than in our country. There are three states with more currency reception and among those is the state of Guanajuato in 3rd place of currency reception.

The Bank of Mexico mentions that they have come to represent the reception of foreign currency the second source of income in the state and this has been a source to combat poverty. The increase in remittance income in the state has been $8.8 \%$ of the peso against the dollar of $20.7 \%$, which marks an increase of $31.3 \%$.

On average, the state of Guanajuato has more than $\$ 2,414$ million foreign exchange. Currencies can have a positive effect on the state in the checking account for transfers that are handled that are foreign income. The negative impact that it can have is the increase that exists on imports since the national product is consumed and economic growth becomes null.

The entry of foreign currency into the state of Guanajuato has exceeded private companies in their economic and labor movement. So far this year, the Bank of Mexico reports that the state of Guanajuato has reached more than one thousand two hundred million dollars in the first quarter of the year per quarter, the amount of 600 million dollars is estimated.

The state of Guanajuato is the third state in the republic with the highest reception of foreign exchange from the United States and other countries. Migration for several decades is a main source of research since knowing the amount they are paid per hour of work or how much they are paid the hour of work, what are the jobs they perform etc.
The state of Guanajuato is taking the workexport model by placing the foreign exchange input used to support the political economy and this is to support the large transnational corporations that are coming to the state.

Today in the United States it has 320.37 million inhabitants and of that number 36.18 million inhabitants are of Mexican origin and approximately 1 million 11 thousand are Guanajuato in the neighboring country. 84.6 of the migrants in the neighboring country are men at an average age of 29 years and older as soon as they realize there is no job and another economic entry is needed.

\section{Reference Framework}

The financial impact that the state of Guanajuato has for the entry of currencies is very strong since $82 \%$ of migrants are from the state, therefore, it is estimated that 1 in 3 households is related to migration and logically It has currency reception.

The state of Guanajuato is located in the third place in the states of the republic with more foreign exchange. Since currencies are a financial impact for the 46 municipalities of Guanajuato.

The Bank of Mexico has reported in these months of the year have reached the state of Guanajuato more than 200 billion dollars so the quarterly average is 600 million and has been approximated or semiannual increase of $7 \%$ of the currencies that enter to the state The population of the state of Guanajuato in its entirety is $5,486,372$ people, of which $51.9 \%$ are women and $48.1 \%$ men according to the last census that was conducted, and $70 \%$ are from urban areas, our educational level is below of the national index since the state has a high level of illiteracy, so this is because the majority of the population goes abroad to work.

According to the figures of INEGI and the Secretary of Economy in the last census, the state of Guanajuato attracted a foreign investment of 531.2 million dollars, which represented a large economic percentage for the state. 
Regarding remittances, Guanajuato reached a total of 1.708 .3 million dollars during the period January-September 2015p /, which meant a growth of $6.9 \%$ with respect to the same period of the previous year. It ranked 2nd in the country, as it concentrated $9.2 \%$ of the national total.

This year has been very difficult for people who are abroad with the new deportation law by the neighboring country.

An analyst at the research and budgetary center warned that with that number of deportations, a negative effect on the currencies that reach the state will begin to be felt.

A possible fall in foreign exchange that may come from abroad may be due to its president, but those that could be most affected are the border crossing daily and sending money to their families.

\section{Developing}

Currencies are one of the main economic entrances of the state of Guanajuato as well as tourism, but the big difference that exists is that currencies are used to feed and dress families. Over 11 million Mexicans abroad and of these millions a very strong percentage is from Guanajuatenses.

Currency growth has been in very real terms, much favored by the international context, as unemployment rates continue to be presented abroad, as in the state of Guanajuato.

According to analyst David Cervantes, the main source of foreign currency in the United States is Mexico with $94.3 \%$ in total of the first quarters of the current year.

And one of the most prominent entities is the state of Guanajuato since each quarter has a $10 \%$ growth in foreign exchange.

During the first quarters of the year, one of the main means of sending were electronic transfers with $97.8 \%$ but also shipments in effect or kind $1.7 \%$ and finally the payment orders $0.5 \%$.
The national survey of Demographic dynamics that was carried out that is the study carried out by INEGI tells us that 66 thousand Guanajuatenses left the state and the country abroad, being the United States the destination country to find a better economic situation for their family, The percentage of Guanajuatenses is 97.1 inhabitants in different states of the United States, nationally this is the fourth highest percentage of migrants in the neighboring country behind the state of Guanajuato are the states of Michoacán, Guerrero and Nayarit.

INEGI reported this year that the tendency of migrants from Guanajuato to go to the neighboring country has decreased since now only $86.3 \%$ receive migrants since the percentage of migrants to countries such as Canada and Spain has increased.

The main cause of embarking on a trip abroad for men is to be able to change their family's economic situation and because of the unemployment that exists in Mexico, it is not possible that they go in search of the American dream.

The nature of the migratory flow of a community also generates different effects; In this regard, studies have highlighted the effects of remittances on the welfare of migrants, their families and their communities, mainly rural.

Guanajuato is a traditionally migratory entity, since after three generations of emigrants still inhabitants of the various communities leave labor to the United States.

Initially, the migratory flow consisted of agricultural workers, although the presence of new forms of incorporation of emigrants into the labor market abroad meant that this flow is already integrated with workers who work in construction and people who work in others. services. The migratory flow no longer only includes migrants, but also merchants and service providers.

The migratory flow may be apparently similar, but each community builds its own, which first and foremost places the established family and social networks of each place of departure as a priority. For example, communities in the municipalities of southern Guanajuato report California as their main destination.

GÓMEZ-BRAVO, María De La Luz, GOMEZ-BRAVO, Jessica Margarita, ANDRADE-OSEGUERA-Miguel Ángel and BARCENASPUENTE José Luis. Financial impact of foreign exchange entering the state of Guanajuato. Journal of Administration and Finance. 2019 
Seasonal flows of migrant labor are those that leave in March and April or in November and December, it depends a lot on their immigration status: since those who have documents return every six months or every year and those who lack them do so every two years or more.

The main reason for emigration to the neighboring country is to find work, the reason given by the married and even more single people. They point out that now there is less "need" and more to improve the living conditions of families through a well-paid job that allows them to remit money with certain constancy and periodicity.

The departure of the first emigrants had the purpose of saving and returning to their place of origin; then with the improvement of its economic situation, migration appears as the only alternative to work. Thus, migration is presented as a structural, dialectical and longterm process.

Currencies have received special attention in these years for being the easiest way to measure non-commercial exchanges and relations with the communities of origin.

The practical aspect, the Currencies have contributed in an important way to the support of the families, since it is the first reason of the sending of money, but also they have been useful to solve some urgency, to improve or to buy house and to realize some type of investment.

The amount of the Currencies depends on the family member who is in the neighboring country, and the number of inhabitants of the family, the needs they have and the conditions in which the emigrant joins the US market.

Guanajuato emigrants have a wide variety of experiences, which are reflected in the currencies they send. In his homes are his wife and a son under three years of age, who must send a good amount of currency to support his family in good condition.
Guanajuato: Number of emigrants by migratory mode

Percentage

Labor and return

Labor only (ML)

11131555.1

Return Only (MRT)

Total Migrants 202039
7713138.2
135936.7
100.0

In the various jobs have been found or that temporary emigrants are found they carry money for their trip back to Mexico this is known as "pocket transfer".

But for this it is necessary to know the form of return of the temporary emigrant, since the proportion of those who make shipments, the average of dollars sent per month and the part of emigrants who make pocket transfers and their amount (Corona)

Methodology

It will be Qualitative since data collection without numerical measurement is used to discover or refine research questions in the interpretation process, Qualitative studies can develop questions and hypotheses before, during or after data collection and analysis.

Qualitative data make detailed descriptions of situations, events, people, interactions, observed behaviors and their manifestations. The qualitative approach mainly seeks "dispersion or expansion" of data and information, reflection is the bridge that links the researcher.

The qualitative approach studies the various subjective realities constructed in the investigation, which vary in their form and content among individuals, groups and cultures, the reality if it changes by observations and data collection, describes and interprets the phenomena through perceptions and meanings produced by the experience of the participants.

The qualitative approach provides depth to the data contextualization of the environment or environment and unique experiences, as well as provides a "fresh, natural and holistic" view of the phenomena, as well as flexibility.

The orientation towards the description prediction and explanation is directed towards measurable or observable data. 
The goal of mixed research is not to replace quantitative and qualitative research, but to use the strengths of both types of inquiry by combining them and trying to minimize their potential weaknesses.

The mixed methods represent a set of systematic, empirical and critical research processes and involves the collection and analysis of qualitative and quantitative data, as well as their integration and joint discussion to make inferences as a result of all information collected and achieve their greater understanding of the phenomenon under study.

They are the systematic integration of qualitative and quantitative methods in a single study to obtain a more complete picture of the phenomenon, these can be combined in such a way that qualitative and quantitative approaches retain their original structure and procedures.

\section{Conclusion}

The early age of the first departure of men to the United States affects two social processes: 1) it increases the desertion of men in secondary school 2) the opportunities for women to marry significantly decrease.

Returning emigrants invest in Guanajuato, as many are "partners" of the American employer, who disburses the money and the former immigrant serves as the company's administrator.

The importance of foreign exchange has led the state government to carry out a financial and a productive program. The first one intends to establish a joint investment fund between the currencies and the state government support and that for every dollar remitted by the emigrants, the state government will put two, this will give rise to a development fund for the communities of origin of the emigrants who will enter the program

Currency is a source of support for family consumption, home improvement and basic urban services and in cases they have productive effects when they are used for investment. This depends on the degree reached by the localities on the economic ties between the members of the communities and the importance of the Currencies with respect to the other income of the community.
Migration has downplayed the labor market mainly in young people and this constitutes a loss of human capital, as people leave at an economically active and productive age; That is why the investment of Mexican society in education, health and social infrastructure will have to be added.

\section{References}

Fernando Lozano, "La migración internacional y remesas: cambios en el quinquenio 1990-1995", Memoria del Coloquio Internacional sobre Migración Mexicana a Estados Unidos, Guanajuato, México

Instituto Nacional de Estadística y Geografía, Secretaría de Economía. Estadísticas de Exportaciones por Entidad Federativa <http://www.economia.gob.mx/files/delegacion es/tabulados_exportaciones_entidad_federativa Secretaría de Economía. Cifras notificadas y actualizadas

〈http://www.economia.gob.mx/comunidadnegocios/competitividadnormatividad/inversion-extranjeradirecta/estadisticaoficial-de-ied-en-mexico〉 3 Banco de México (BANXICO), enero septiembre. 